\title{
Factors Influencing the Intention to Use Technology Services to Implement Self-Service Technology Case Study: Situation Pandemic Covid-19
}

Erick Fernando ${ }^{1, *}$, Surjandy Surjandy ${ }^{1}$, Meyliana Meyliana ${ }^{1}$, Henry Antonius Wijadja ${ }^{1}$, Desman Hidayat ${ }^{2}$, Ary W Kusumaningtyas ${ }^{3}$, Roni Heryatno ${ }^{3}$

${ }^{1}$ School of Information Systems, Information Systems Department, Bina Nusantara University, Jakarta, 11480, Indonesia

${ }^{2}$ BINUS Entrepreneurship Center, Management Department, Bina Nusantara University, Jakarta, 11480, Indonesia

${ }^{3}$ BINUS Entrepreneurship Center, Global employability and entrepreneurship, Bina Nusantara University, Jakarta, 11480, Indonesia

A R T I C L E I N F O

Article history:

Received: 03 July, 2020

Accepted: 16 August, 2020

Online: 17 September, 2020

Keywords:

Adoption technology

Self-Service Technology

Covid-19

\begin{abstract}
A B S T R A C T
This study aims to analyze a person's intention in using self-service technology (SST) services during the pandemic COVID-19. Where this time, raising problems one of the social distancing that affects a service provided, especially on services that use technology that applies SST. This study develops from previous research where the customer has satisfaction in using SST services. Still, this use does not know a person intention to use SST services, so it is necessary to develop with several factors the adoption of technology, namely influence that can make a person intention to use. The research framework of this research consists of several factors and indicators, namely efficiency (4 indicators), Reliability (4 indicators), security (3 indicators), Convenience (3 indicators), Ease of use (4 indicators). This study uses an online survey with google form for users of self-service technology services in 5 major cities in Indonesia. Dissemination of the survey for three months, and the obtained were 100 respondents valid. This research conducts testing using Smarpls v3.0. The results of this study found two factors that influence perceived usefulness, namely: efficiency and reliability, and found three factors that did not have an impact, namely Security factors, Convenience Factors, Perceived Ease of use, and Service Trust do not have an impact on perceived usefulness. This result is a very interesting finding because during the period pandemic COVID-19. These factors are no longer the top priority in the use of SST services and do not affect who intention to use a technology service. Thus, it can be concluded that whose intention at a certain level of the problem will prioritize the reliability and efficiency of the system for service. This factor can be the focus of the company in developing systems that adopt Self-service technology.
\end{abstract}

\section{Introduction}

During the pandemic COVID-19 disease that has adversely affected various sectors of human life in various countries, these sectors include the industrial sector, the education sector, the tourism sector and other sectors[1]-[3]. Adverse impacts are influenced by social distancing (giving social distance) between humans, thereby reducing services provided between people[2, 3]. Thus, various industrial sectors require a large technological role to help overcome the various problems that arise, with the development of industry 4.0, which is an integrated industry and provides a service system automation. Therefore, this automation service must use self-service technology services.

"Corresponding Author: Erick Fernando, erick.fernando_88@yahoo.com www.astesj.com

https://dx.doi.org/10.25046/aj050542
Self-service technology (SST) is a technology that provides independent services to customers without involving the assistance of services from people[4]-[6]. Services that use SST include the current banking industry very much from automated teller machine (ATM), mobile services and internet banking to current account opening services, trading industry including order services and self-purchase with web or mobile services namely ecommerce, the healthcare industry with automated consulting services, and other company services provided to customers in the form of customer relationship management [4].

The role of the current application of SST in the industry sector provides solutions to companies and provides benefits in reducing operational and labor costs. However, the application of SST in 
various industrial sectors must be able to know the factors that influence the intention to use it. The SST implementation must be able to be used correctly by the user continuously, so the developed technology must be able to increase the intention to use it.

In this article, we focus on discussing and analyzing the factors that influence intention to use in using technology that implemented SST. This article provides two very important contributions focuses. First, this study uses a technology acceptance model (TAM) [7] that is integrated with SST. Second, the construction of the model construct adds one independent variable, namely service trust. Because the service trust studied previously is very influential in the SST service [8]. The development of this model can provide usefulness and Ease of use as well as the intention of someone using it to broaden their understanding of SST acceptance and the mechanisms that must be prepared in the application of SST in various industrial sectors [8].

\section{Literature}

Self-service technology is an innovative technology that allows customers to take advantage of services without the involvement of service employees [4]. Self-service technology (SST) can also be interpreted as a business that uses a technology interface to provide the best communication to consumers in the transaction process of products or services provided by the company [9]. The application of SST to customers must provide satisfaction to customers from the experience of using SST and influence the desire of customers to return and intention to use [10]. Examples of SST transactions are : bank transactions through automated teller machines (ATM), SPBU, shopping via the internet, vending machines, internet banking, phone banking, making reservations and purchasing tickets through online kiosks [4].

The role of technology is very high in a service provided by a company or industry, especially SST. SST has a factor of perceived usefulness (PU) that has a very important role in people intention to use a service [5]. Thus, technology can hopefully be used to serve all the needs of users. Users of technology services, especially self-service, can be used for a small risk when using them. This gives a perfect sense of trust in a service. Therefore, the use of technology in SST is influenced by a sense of trust in SST to bring up people the intention to use it $[11,12]$. User experience in the use of services with high trust can have a substantial impact on perceived usefulness $[6,8,13]$. The experience of using the services will be influenced by the Ease of use of the service, so it will indirectly affect people's intentions to use technology that implements SST.

The use of Self-Service Technology that is implemented must be able to improve service convenience and provide efficient service processes to customers. Therefore, SST must provide fast services with a shorter time to complete transactions that reduce activity costs. Then the development of SST must provide reliable system reliability to respond to all customer requests on the system. In addition, security in the use of systems that implementation SST to transaction data until the customer's personal data becomes an important thing that must be considered.

\section{Conceptual Framework}

This study develops from previous research by [14] where the customer has a satisfaction in using SST services, but this user does not know people intention to use SST services, so it is necessary to develop with several factors the adoption of technology [7] namely influence that can make people for intention to use this SST service that is perceived usefulness, perceived Ease of use, intention use. So the research framework developed as follows

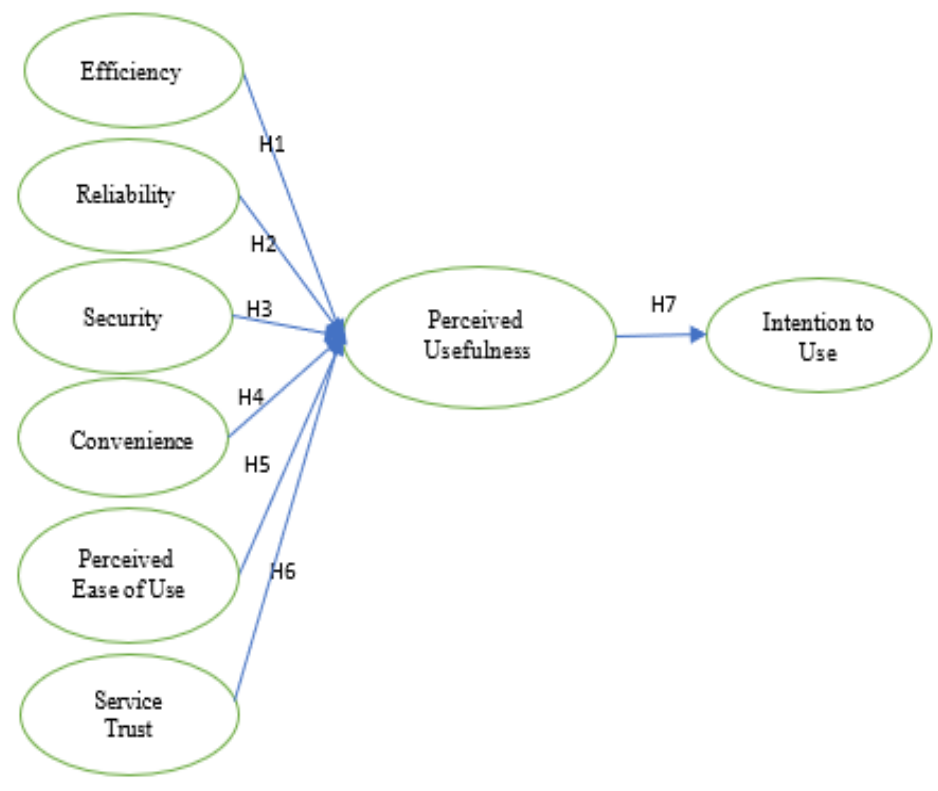

Figure 1: Research Framework

All of these things provide a positive user experience so that users intend to use it continuously and can also provide recommendations to other users. Therefore, the following hypothesis is proposed:

- H1. Efficiency in SST services has a positive impact on perceived usefulness.

- H2. Reliability in SST services has a positive impact on perceived usefulness.

- H3. Security in SST services has a positive impact on perceived usefulness.

- H4. Convenience in SST services has a positive impact on perceived usefulness.

- H5. Perceived Ease of use in SST services has a positive impact on perceived usefulness.

- H6. Service Trust in SST services has a positive impact on perceived usefulness.

- $\quad \mathrm{H} 7$ perceived usefulness in SST services has a positive impact on intention to Use.

\section{Methodology}

\subsection{Research Design}

This study uses an online survey with Google form for users of self-service technology services in 5 major cities in Indonesia. Services used include ATM, internet banking, mobile banking, and independent check-in machines at airports, toll payments, service queue numbers, online shopping, gas stations, finding machines for food and beverages. Respondents taken have used one or more SST services. Dissemination of the survey for 3 months, and the respondents obtained were 100 people. 
Table 1: Respondent characteristic

\begin{tabular}{|c|c|c|}
\hline \multicolumn{2}{|c|}{ Characteristic } & $\%$ \\
\hline \multicolumn{3}{|c|}{ Gender } \\
\hline & Male & 65 \\
\hline & Female & 35 \\
\hline \multicolumn{3}{|c|}{ Age } \\
\hline & Less 20 & 15 \\
\hline & $21-25$ & 25 \\
\hline - & $26-30$ & 37 \\
\hline- & $31-35$ & 18 \\
\hline - & $36-40$ & 3 \\
\hline & Over 40 & 2 \\
\hline \multicolumn{3}{|c|}{ Education } \\
\hline- & Student & 18 \\
\hline & Bachelor & 42 \\
\hline & Master & 30 \\
\hline & $\mathrm{PhD}$ & 10 \\
\hline \multicolumn{3}{|c|}{ Self-Service Technology Users } \\
\hline- & Self-check-in at airport & 10 \\
\hline- & ATM & 25 \\
\hline- & SPBU & 8 \\
\hline- & Tol Payment & 20 \\
\hline- & Internet Banking & 10 \\
\hline & Mobile Banking & 10 \\
\hline & Online Shopping & 15 \\
\hline & vending machine & 2 \\
\hline
\end{tabular}

\subsection{Development variable}

Development of the instrument used in this study is the result of the adoption of several constructs that have been used in previous research. Constructs and indicators are modified to make the instrument in accordance with the current research context.

Table 2: Development Variable and instrument

\begin{tabular}{|l|l|l|}
\hline Variable & Symbol & Instrument \\
\hline Service Trust & ST1 & $\begin{array}{l}\text { I believe that the transaction system } \\
\text { in the self-service technology } \\
\text { service is secure (ex. Toll payment, } \\
\text { E-commerce payment, bank print } \\
\text { service, laundry service, and other } \\
\text { services) }\end{array}$ \\
\cline { 2 - 3 } & ST2 & $\begin{array}{l}\text { I believe the transaction process } \\
\text { and the results of the Self-service } \\
\text { technology are correct (ex. Toll } \\
\text { payments, E-commerce payments, } \\
\text { bank print services, laundry } \\
\text { services, and other services) }\end{array}$ \\
\cline { 2 - 3 } & ST3 & $\begin{array}{l}\text { I believe that the self-service } \\
\text { technology available makes } \\
\text { security increased }\end{array}$ \\
\cline { 2 - 3 } & ST4 & $\begin{array}{l}\text { I believe that the filling process } \\
\text { carried out with self-service } \\
\text { technology is easy to do }\end{array}$ \\
\hline Security & S1 & $\begin{array}{l}\text { Overall, I am satisfied with the } \\
\text { Self-service technology provided }\end{array}$ \\
\hline
\end{tabular}

\begin{tabular}{|c|c|c|}
\hline Variable & Symbol & Instrument \\
\hline & S2 & $\begin{array}{l}\text { I made the right decision to use self- } \\
\text { service technology }\end{array}$ \\
\hline & S3 & $\begin{array}{l}\text { I can easily recommend self-service } \\
\text { technology to my friends and others }\end{array}$ \\
\hline \multirow[t]{3}{*}{ Convenience } & $\mathrm{C} 1$ & $\begin{array}{l}\text { Self-service technology can be } \\
\text { accessed at any time }\end{array}$ \\
\hline & $\mathrm{C} 2$ & $\begin{array}{l}\text { Self-service technology provisions } \\
\text { allow me to make transactions } \\
\text { anywhere }\end{array}$ \\
\hline & $\mathrm{C} 3$ & $\begin{array}{ll}\begin{array}{l}\text { Self-service technology is } \\
\text { convenient to use }\end{array} & \text { is } \\
\end{array}$ \\
\hline \multirow[t]{4}{*}{$\begin{array}{l}\text { Perceived } \\
\text { usefulness }\end{array}$} & PE1 & $\begin{array}{l}\text { It's easy to become an expert in } \\
\text { using the Self-service technology } \\
\text { provided }\end{array}$ \\
\hline & PE2 & $\begin{array}{l}\text { Self-service technology has clear } \\
\text { instructions }\end{array}$ \\
\hline & PE3 & $\begin{array}{l}\text { The Self-service technology } \\
\text { provided by is easy to use }\end{array}$ \\
\hline & PE4 & $\begin{array}{l}\text { Interacting with the system does not } \\
\text { require much mental effort }\end{array}$ \\
\hline \multirow[t]{4}{*}{ Reliability } & $\mathrm{R} 1$ & $\begin{array}{l}\text { I get accurate and error-free } \\
\text { services from self-service } \\
\text { technology (ex. Toll payments, E- } \\
\text { commerce payments, bank printing } \\
\text { services, laundry services, and } \\
\text { other services) }\end{array}$ \\
\hline & $\mathrm{R} 2$ & $\begin{array}{l}\text { I can depend on the services } \\
\text { provided through self-service } \\
\text { technology (Expert insight) }\end{array}$ \\
\hline & R3 & $\begin{array}{l}\text { The Self-service technology } \\
\text { completes my selected transactions } \\
\text { within the allotted time }\end{array}$ \\
\hline & $\mathrm{R} 4$ & Self-service technology is Reliable \\
\hline \multirow[t]{4}{*}{ Efficiency } & $\mathrm{EF} 1$ & $\begin{array}{l}\text { Self-service technology provides } \\
\text { fast service with shorter waiting } \\
\text { times }\end{array}$ \\
\hline & $\mathrm{EF} 2$ & $\begin{array}{l}\text { Self-service technology saves me } \\
\text { time }\end{array}$ \\
\hline & EF3 & $\begin{array}{l}\text { Self-service technology allows me } \\
\text { to complete transactions quickly }\end{array}$ \\
\hline & EF4 & $\begin{array}{l}\text { Self-service technology reduces the } \\
\text { cost of my activities }\end{array}$ \\
\hline \multirow[t]{5}{*}{$\begin{array}{l}\text { Perceived of } \\
\text { use }\end{array}$} & PU1 & $\begin{array}{l}\text { I think using services Self-service } \\
\text { technology can make } \\
\text { understanding more efficient }\end{array}$ \\
\hline & PU2 & $\begin{array}{l}\text { I think using a self-service } \\
\text { technology will not be limited by } \\
\text { time and location, which is very } \\
\text { helpful for me }\end{array}$ \\
\hline & PU3 & $\begin{array}{l}\text { By using Self-service technology } \\
\text { services, I realize the extraordinary } \\
\text { development of technology }\end{array}$ \\
\hline & PU4 & $\begin{array}{l}\text { I think I can get payment } \\
\text { information quickly using the Self- } \\
\text { service Technology service }\end{array}$ \\
\hline & PU5 & $\begin{array}{l}\text { I think using the service Self- } \\
\text { service technology can make life } \\
\text { more comfortable }\end{array}$ \\
\hline
\end{tabular}




\begin{tabular}{|c|c|c|}
\hline \multirow[t]{3}{*}{ Variable } & Symbol & Instrument \\
\hline & PU6 & $\begin{array}{l}\text { Self-service technology helps me } \\
\text { learn to operate the tool }\end{array}$ \\
\hline & PU7 & $\begin{array}{l}\text { Self-service technology provided } \\
\text { helped me to live more } \\
\text { economically }\end{array}$ \\
\hline \multirow[t]{6}{*}{$\begin{array}{l}\text { Intention to } \\
\text { Use }\end{array}$} & IU1 & $\begin{array}{l}\text { I want to use the self-service } \\
\text { technology provided }\end{array}$ \\
\hline & IU2 & $\begin{array}{l}\text { I want to use the Self-service } \\
\text { technology service to link the } \\
\text { payment and purchase information }\end{array}$ \\
\hline & IU3 & $\begin{array}{l}\text { I continue to increase the frequency } \\
\text { of use of self-service technology } \\
\text { services }\end{array}$ \\
\hline & IU4 & $\begin{array}{l}\text { I believe the frequency of use of } \\
\text { self-service technology in the future } \\
\text { will continue to increase }\end{array}$ \\
\hline & IU5 & $\begin{array}{l}\text { I always re-use the Self-Service } \\
\text { Technology }\end{array}$ \\
\hline & IU6 & $\begin{array}{l}\text { I will use the Self-service } \\
\text { technology whatever happens later }\end{array}$ \\
\hline
\end{tabular}

\subsection{Measurement}

This study modified the model developed [14], namely: efficiency (4 indicators), reliability (4 indicators), security (3 indicators), Convenience (3 indicators), Ease of use (4 indicators),

adding one Important factor according to Hee-Dong Yang [8] are service trust (4 indicators) and with several factors of technology adoption developed [7], so that one can find out someone who intention to use this SST service namely perceived usefulness (7 indicators), perceived Ease of Use (4 indicators), intention use (6 indicators). This study uses a measurement scale point 6 with the type of interval data that aims to get a more specific response picture of the respondents.

\section{Result}

This research conducts testing using Smartpls v3.0 because the research framework has a latent construct. The test was initiated by testing the validity using a loading factor value greater than 0.5 and reliability using an average variance extracted (AVE) value greater than 0.5 , composite reliability $(\mathrm{CR})$ greater than 0.6 , and Cronbach alpha greater than 0.6 [15].

Table 3: Reliability Test

\begin{tabular}{|l|c|c|c|}
\hline & Cronbach'alpha & CR & AVE \\
\hline Convenience & 0.848 & 0.904 & 0.758 \\
\hline Efficiency & 0.929 & 0.95 & 0.825 \\
\hline Intention use & 0.939 & 0.953 & 0.772 \\
\hline Perceived ease of use & 0.93 & 0.95 & 0.826 \\
\hline Perceived usefulness & 0.936 & 0.948 & 0.725 \\
\hline Reliability & 0.935 & 0.954 & 0.838 \\
\hline Security & 0.926 & 0.953 & 0.871 \\
\hline Service trust & 0.897 & 0.929 & 0.766 \\
\hline
\end{tabular}

Table 4: Validity test

\begin{tabular}{|c|c|c|c|c|c|c|c|c|}
\hline & Convenience & Efficiency & $\begin{array}{c}\text { Intention } \\
\text { Use }\end{array}$ & $\begin{array}{l}\text { Perceived } \\
\text { Ease of use }\end{array}$ & $\begin{array}{l}\text { Perceived } \\
\text { usefulness }\end{array}$ & Reliability & Security & $\begin{array}{c}\text { Service } \\
\text { Trust }\end{array}$ \\
\hline $\mathrm{C} 1$ & 0.888 & & & & & & & \\
\hline $\mathrm{C2}$ & 0.887 & & & & & & & \\
\hline $\mathrm{C3}$ & 0.836 & & & & & & & \\
\hline EF1 & & 0.922 & & & & & & \\
\hline EF2 & & 0.945 & & & & & & \\
\hline EF3 & & 0.942 & & & & & & \\
\hline EF4 & & 0.820 & & & & & & \\
\hline IU1 & & & 0.927 & & & & & \\
\hline IU2 & & & 0.951 & & & & & \\
\hline IU3 & & & 0.935 & & & & & \\
\hline IU4 & & & 0.876 & & & & & \\
\hline IU5 & & & 0.664 & & & & & \\
\hline IU6 & & & 0.886 & & & & & \\
\hline PE1 & & & & 0.862 & & & & \\
\hline PE2 & & & & 0.920 & & & & \\
\hline PE3 & & & & 0.934 & & & & \\
\hline PE4 & & & & 0.918 & & & & \\
\hline PU1 & & & & & 0.911 & & & \\
\hline PU2 & & & & & 0.854 & & & \\
\hline PU3 & & & & & 0.897 & & & \\
\hline PU4 & & & & & 0.896 & & & \\
\hline PU5 & & & & & 0.894 & & & \\
\hline PU6 & & & & & 0.770 & & & \\
\hline PU7 & & & & & 0.718 & & & \\
\hline
\end{tabular}




\begin{tabular}{|c|c|c|c|c|c|c|c|c|}
\hline & Convenience & Efficiency & $\begin{array}{c}\text { Intention } \\
\text { Use }\end{array}$ & $\begin{array}{c}\text { Perceived } \\
\text { Ease of use }\end{array}$ & $\begin{array}{l}\text { Perceived } \\
\text { usefulness }\end{array}$ & Reliability & Security & $\begin{array}{c}\text { Service } \\
\text { Trust }\end{array}$ \\
\hline R1 & & & & & & 0.916 & & \\
\hline $\mathbf{R 2}$ & & & & & & 0.939 & & \\
\hline R3 & & & & & & 0.919 & & \\
\hline R4 & & & & & & 0.886 & & \\
\hline S1 & & & & & & & 0.940 & \\
\hline S2 & & & & & & & 0.919 & \\
\hline $\mathbf{S 3}$ & & & & & & & 0.940 & \\
\hline ST1 & & & & & & & & 0.907 \\
\hline ST2 & & & & & & & & 0.949 \\
\hline ST3 & & & & & & & & 0.833 \\
\hline ST4 & & & & & & & & 0.804 \\
\hline
\end{tabular}

\section{A. Evaluate the model}

Evaluate the model using the "coefficient of determination" value (R2) and the value of "Path coefficient", where the value according to the hair must be greater than 0.5 . The results of the evaluation are the perceived usefulness of 0.911 and the intention to use 0.809 so that the model is a very fit model.

\section{B. Hypotheses Test}

Hypothesis testing using the standard $\mathrm{p}$-value value, according to hair p-value, must be less than 0.005 , then the hypothesis is accepted / significant while the opposite is rejected / not significant. Hypothesis test results are found, namely: Hypothesis 1 testing gets a p-value of 0,000 , so it can be concluded that efficiency greatly affects the perceived usefulness. Testing Hypothesis 2 gets a p-value of 0.035 so that it can be concluded that reliability greatly affects the perceived usefulness. Testing Hypothesis 3 gets a p-value of 0.526 , so it can be concluded that security has no impact on perceived usefulness. Testing Hypothesis 4 gets a p-value of 0.663 , so it can be concluded that Convenience does not have an impact on perceived usefulness. Testing Hypothesis 5 gets a p-value of 0.626 , so it can be concluded that the perceived Ease of use has no impact on perceived usefulness. Testing Hypothesis 6 gets a p-value of 0.735 , so it can be concluded that Service Trust has no impact on perceived usefulness. Hypothesis 6 testing gets a p-value of 0.000 , so it can be concluded that perceived usefulness has an impact on the Intention to Use.

\section{Conclusion}

The results of this study indicate that factors influence whether or not someone who intention in using SST services. The efficiency factor greatly affects perceived usefulness. This is in accordance with previous studies that describe that the efficiency of SST services is needed to make transactions carried out quickly so as to provide a reduction in costs and time required by customers $[6,14,16]$. So on its own, increasing its use will affect someone who intends to use it. The reliability factor greatly affects perceived usefulness. This is consistent with previous research, which states that a reliable system can improve services as much as the user wants, which requires precision, good consistency of a system. This directly increases to someone who intends to use SST services $[10,14,17-19]$. Security factors, Convenience Factors, Perceived Ease of use, and Service Trust do not have an impact on perceived usefulness. The findings of the study contradict the previous studies which stated that the safety, simplicity, and Ease of use of the system are highly considered by users when they want to use technology. Therefore, the results of this study make a very interesting finding because it happened during the Covid-19 pandemic that made these factors no longer a priority in the use of SST services and did not affect someone who intended to use technology services. Therefore, it can be concluded that someone whose intention is at a certain level of problem will give priority to the reliability and efficiency of the system for services. These factors may be the company's focus on developing a system that implements SST. Researchers in further research can develop discussions on automation factors in SST, if you can augment someone who intends to use SST services because this automation is a new part of Industry 4.0 needs.

\section{Reference}

[1]. M.P.A. Murphy, "COVID-19 and emergency eLearning: Consequences of the securitization of higher education for post-pandemic pedagogy," Contemporary Security Policy, 41(3), 492-505, 2020, doi:10.1080/13523260.2020.1761749.

[2]. R. Vaishya, A. Haleem, A. Vaish, M. Javaid, "Emerging Technologies to Combat the COVID-19 Pandemic," Journal of Clinical and Experimental Hepatology, 10(4), 409-411, 2020, doi:10.1016/j.jceh.2020.04.019.

[3]. M. Javaid, A. Haleem, R. Vaishya, S. Bahl, R. Suman, A. Vaish, "Industry 4.0 technologies and their applications in fighting COVID-19 pandemic," Diabetes and Metabolic Syndrome: Clinical Research and Reviews, 14(4), 419-422, 2020, doi:10.1016/j.dsx.2020.04.032.

[4]. K. Kansana, A. Tripathi, D.- Issues, "Understanding Self Service Technologies," (September), 2019.

[5]. V. Ong, N.M. Yee, G.J. Hui, N. Kasim, I. Hizza, "The Impact of Service Automation on Customer Satisfaction and Customer Retention: An Empirical Study of Malaysian Rail Transportation," Proceedings of 4th Global Business and Finance Research Conference, (May), 2015.

[6]. M. Sedighimanesh, A. Sedighmanesh, N. Ashghaei, "The Impact Of SelfService Technology On Customer Satisfaction Of Online Stores," International Journal of Scientific \& Technology Research, 06(07), 172-178, 2017.

[7]. F.D. Davis, "Perceived Usefulness, Perceived Ease of Use, and User Acceptance of," Information Technolog MIS Quarterly, 13(3), 319--340., 1989, doi:10.2307/249008.

[8]. H.D. Yang, J. Lee, C. Park, K. Lee, "The adoption of mobile self-service technologies: Effects of availability in alternative media and trust on the relative importance of perceived usefulness and ease of use," International Journal of Smart Home, 8(4), 165-178, 2014, doi:10.14257/ijsh.2014.8.4.15.

[9]. N. Taufik, M.H. Hanafiah, "Airport passengers' adoption behaviour towards self-check-in Kiosk Services: the roles of perceived ease of use, perceived usefulness and need for human interaction," Heliyon, 5(12), 2019, doi:10.1016/j.heliyon.2019.e02960.

[10]. N. Robertson, H. McDonald, C. Leckie, L. McQuilken, "Examining customer evaluations across different self-service technologies," Journal of Services Marketing, 30(1), 88-102, 2016, doi:10.1108/JSM-07-2014-0263. 
[11]. L. Zeng, Factors influencing the adoption of self-service technologies: A study of the benefits and risks of self-service technologies and trust beliefs of service providers, 2016.

[12]. D.D. Dugar, "Public Self Service Technology ( SST ): Designing for Trust Factors enhancing user's trust towards a public," 2018.

[13]. H. Oh, M. Jeong, S. Baloglu, "Tourists' adoption of self-service technologies at resort hotels," Journal of Business Research, 66(6), 692-699, 2013, doi:10.1016/j.jbusres.2011.09.005.

[14]. Gunawardana, D. Kulathunga, H.M.R.S.S. Perera, W.L.M.V., "Impact of Self Service Technology Quality on Customer Satisfaction: A Case ...: EBSCOhost," Gadjah Mada Intemational Joumal of Business, 17(1), 1-24, 2015.

[15]. J.F. Hair Jr, G.T.M. Hult, C. Ringle, M. Sarstedt, A primer on Partial Least Squares Structural Equation Modeling (PLS-SEM), Sage Publications, Singapore, 2013.

[16]. C.K.M. Lee, Y. Ng, Y. Lv, P. Taezoon, "Empirical analysis of a self-service check-in implementation in Singapore Changi Airport," International Journal of Engineering Business Management, 6(1), 33-44, 2014, doi:10.5772/56962.

[17]. H. Iberahim, N.K. Mohd Taufik, A.S. Mohd Adzmir, H. Saharuddin, "Customer Satisfaction on Reliability and Responsiveness of Self Service Technology for Retail Banking Services," Procedia Economics and Finance, 37(16), 13-20, 2016, doi:10.1016/s2212-5671(16)30086-7.

[18]. P.S. Otieno, K. Govender, "Managing airport service quality - The impact of self-service technologies," Investment Management and Financial Innovations, 13(3), 387-393, 2016, doi:10.21511/imfi.13(3-2).2016.11.

[19]. J.S.C. Lin, P.L. Hsieh, “Assessing the Self-service Technology Encounters: Development and Validation of SSTQUAL Scale," Journal of Retailing, 87(2), 194-206, 2011, doi:10.1016/j.jretai.2011.02.006. 